\title{
Exploring the Links between Stakeholder Type, and Strategic Response to Stakeholder and Institutional Demands in the Public Sector Context
}

\author{
Grainne Oates ${ }^{1}$ \\ ${ }^{1}$ Swinburne University of Technology, Australia \\ Correspondence: Grainne Oates, Swinburne University of Technology, Australia. E-mail: goates@swin.edu.au
}

Received: August 20, 2013

Accepted: September 10, 2013

Online Published: October 15, 2013

doi:10.5539/ijbm.v8n21p50

URL: http://dx.doi.org/10.5539/ijbm.v8n21p50

\begin{abstract}
The management of increased numbers of stakeholder groups with increased and conflicting demands requires refined information on who and what really counts to management in terms of these demands from multiple stakeholders. These requirements challenge stakeholder and institutional theory to effectively support the decision making practice. The purpose of this paper is to examine links between stakeholder theory and institutional theory in a way not previously seen in the literature and present new propositions as a potential extension of these theories. The study makes use of the Mitchell et al. (1997) stakeholder typology model and combines it with the Oliver (1991) model which offers a typology of strategic responses to institutional pressures. This is a conceptual paper which employs a literature based analysis and from this generates six new propositions. These propositions can be tested in future research. The main implication is that the paper has the potential to assist managers in dealing with multiple stakeholders' interests. Several insights are provided for further research and for improvement in current practice.
\end{abstract}

Keywords: decision making, public sector, stakeholder theory, institutional theory, strategic responses, stakeholder type

\section{Introduction}

In recent years, managers of organisations have had to respond to more stakeholder groups than ever before, and have had to respond to more demands from these stakeholders. Stakeholder groups may include shareholders, government regulators, government funders, industry lobby groups, environmental and other social interest groups, community groups, professional organisations, trade unions - the list goes on (Oates \& Kloot, 2013). Stakeholder groups may (and often do) have conflicting demands and priorities. There are several different theoretical models which may be used to explain how and why managers respond as they do to diverse stakeholders. Some of these models may have conflicting perspectives; others have similar and seemingly consistent perspectives. Bringing together insights from congruent models may have a synergistic effect in enhancing our understanding of stakeholder management.

There has been a vast amount of research conducted using Mitchell et al's. (1997) stakeholder typology model and more so Oliver's (1991) institutional theory model. This paper seeks to merge the Oliver and Mitchell et al models, to offer an enhanced theoretical perspective on organisational responses to various stakeholder demands. The paper, in presenting six new propositions from this combination, offers new insights into the relationship of managers, organisational responses, and diverse groups of stakeholders.

I seek to develop a merged model in the particular context of the public sector. In a post New Public Management (NPM) world, an enhanced explanatory model may offer new insights into why the public sector, which has been extensively researched over the last two decades, continues to struggle with decisions on balancing economic and social objectives and thus meeting the demands of stakeholders with conflicting objectives (Smith et al. 2013).

It is important to understand how organizations perceive their obligations to their stakeholders and just what they perceive they need to achieve. Organizational performance is related to organizational objectives, and these objectives will be partly determined by the organizational response to conflicting stakeholder demands. This is particularly the case in corporatised public sector entities which have at times conflicting objectives of community 
service in addition to profit objectives.

Stakeholders can influence and exert pressure on an organisation's management. The attributes these stakeholders possess is said to influence the way management respond to their stakeholders (Mitchell et al., 1997). The model predicts that if a stakeholder has all three attributes of power, legitimacy and urgency and is thus considered definitive, this stakeholder's demands will be prioritised above stakeholders with only one or two attributes. However, the model does not offer a prioritisation option if for example an organisation has identified more than one definitive stakeholder. The strategic response model of Oliver (1991) predicts the strategic response of management to stakeholders' demands. This paper combines these two models to predict the strategic response taken by management to the different types of stakeholders. This has not been done previously. I develop six new propositions from the combination of these two well-known models.

The aim of this paper is to expand scholarly and management understanding beyond the three attributes of power, legitimacy and urgency of the Mitchell et al model to include further elements such as the notion of strategic responses of the Oliver model. The addition of these proposed vital dimensions could have the potential to result in more effective management.

The next section of this paper examines some of the notions of stakeholder theory and institutional theory. This is followed by the development of theoretical propositions. I conclude the paper by indicating the implications of these propositions and areas for future research.

\section{Stakeholder Theory}

Whether public or private the environment in which an organisation sits comprises stakeholders or actors. Freeman (1984) recounted the origins of the stakeholder concept, which was used for the first time at the Stanford Research Institute in 1963; stakeholders were first defined as: 'Those groups without whose support the organisation would cease to exist.' Freeman $(1984,31)$ extended this definition. He defines a stakeholder as 'Any group or individual who can affect or is affected by the achievements of an organisation's objectives'. Since 1984, much research has centred on stakeholder theory. Between 1984 and 2007, 179 articles directly addressed Freeman's work on stakeholder theory (Laplume, Sonpar, \& Litz, 2008:1152).

'Much of the argument behind stakeholder theory is that economic pressures to satisfy only shareholders is short-term thinking and organisations need to ensure their survival and success in the long term by satisfying other stakeholders as well.' (Collier, 2008, pp. 935). This is especially important where the focus of the organisation is not that of maximising of shareholder wealth but providing a service or product to the community on behalf of government. The survival and success of these organisations are based not only on satisfying short-term economic performance but also on satisfying multiple stakeholders over the long-term.

For any organisation its stakeholders must be identified. It can be a complex matter to define stakeholders. For example, Kloot \& Martin (2000: 237) define stakeholders in the context of local government:

'The concept of 'stakeholders' is problematic when applied to Australian local government as there is a diversity of groups often with different interests, for example the state government, which provides funding and the legislative framework under which local government operates. Obvious stakeholders include the federal government (which provides some funding), ratepayers, the wider local community, consumers and clients of local government services, while employees, councillors and suppliers have significant interests in issues affecting local government.'

The competing interests of stakeholders make it difficult for management to balance their responsibilities. Management therefore needs to identify and prioritise the demands or requirements of their most influential stakeholders. Mitchell et al. (1997) developed a typology of stakeholder salience and stakeholder identification to capture management's perceived view of prioritisation of stakeholder relationships.

Fundamentally, the stakeholder argument is that organisations should have an interest in all stakeholders and not just shareholders. Laplume et al. (2008:1153) suggest stakeholder theory is 'timely yet adolescent, controversial yet important' due to the emergence of formal organisations, the lack of empirical validity on key propositions (Jones 1995), the questioning of the conventional assumption that the pursuit of profit is management's main concern (Jensen 2002; Harrison et al., 2013) and the importance of how organisations affect society (Smith et al., 2013; Hinings \& Greenwood, 2002; Stern \& Barley, 1996). This research utilises institutional theory to enhance extant stakeholder theory.

The current dominant theory of the firm is the economic model, with a focus on shareholders. Over the last two decades scholars have called for a new theory, which would more accurately describe firm behaviour by focusing on stakeholder relationships (Bundy et al., 2013; Edgley et al., 2010; René Orij, 2010; Mäkelä \& Näsi, 
2010; Darnell et al., 2009; Brenner \& Cochran, cited in Mitchell et al 1997; Donaldson \& Preston, 1995; Hosseini \& Brenner, 1992; Jones 1995; Wood 1991). This theory would explain firm behaviour by integrating observed social behaviour with observed economic performance (Key, 1999). Brenner \& Cochran, (cited in Mitchell et al., 1997) suggested that the stakeholder model might be an alternative to the current economic model. More recently Bucholtz\& Rosenthal (2004, pp. 144) suggest 'stakeholder theory is considered to be something of an alternative to government regulation.' The global financial crisis (GFC) suggests a focus wider than shareholder and economic performance is not only important to society, but also necessary for long-term survival of the firm (Verbeke et al., 2013). During the GFC some of the world's largest and wealthiest institutions collapsed under the strain of adhering to the economic model of the firm, maximising shareholder wealth. In contrast, government organisations have a wider focus as they balance economic and social motives. The government is 'the only entity that has the legitimacy to speak for society as a whole and can thus change the way corporations are governed and managed' (Buchholz \& Rosenthal, 2004: 149). Given this government owned organisations have the potential to lead change and lead to a new theory of the firm.

\subsection{The Mitchell, Agle and Wood (1997) Model}

Mitchell et al. (1997) developed a typology model to predict stakeholder salience and identification to capture management's views of their stakeholders. While there have been competing typologies for example (Elijido-Ten et al., 2010; Friedman \& Miles, 2002; Clarkson, 1995; Frooman, 1999) the Mitchell et al. (1997) model is widely recognised as one of the most influential contributions to stakeholder theory. The model is based on stakeholder attributes. Mitchell et al. (1997) concluded that the three attributes which force managers to pay attention to stakeholders are power, legitimacy and urgency. These attributes have reasonable empirical support (Agle et al., 1999; Boesso\& Kumar, 2007; Currie et al., 2009; Eesley\& Lennox, 2006; Knox \&Gruar, 2007; Parent \& Deephouse, 2007; Winn, 2001). One attribute can be more influential than another. For example, O'Higgins \& Morgan (2006:73) found 'The presence of the legitimacy attribute is more likely than power or urgency to encourage a party to assign salience to a stakeholder'. Parent \& Deephouse (2007) found the attribute power to have the most effect on salience, followed by urgency and then legitimacy. O'Higgins \& Morgan (2006) suggest further attributes could be considered and could broaden or extend the Mitchell et al. (1997) model. They suggest including attributes of ideology and values and believe the ideological dimension appears to be something beyond legitimacy. Overall Currie et al. (2008) find the Mitchell et al. (1997) model provides a pragmatic typology with a justifiable measure of stakeholder salience. The three attributes are defined by Mitchell et al. (1997, pp. 865-866):

'a party to a relationship has power, to the extent it has or can gain access to coercive, utilitarian, or normative means, to impose its will in the relationship. Legitimacy refers to the degree to which a stakeholder relationship with an organisation is seen as appropriate, proper, and desirable in the social context. Urgency exists only when two conditions are met 1) when a relationship or claim is of a time sensitive nature and 2) when that relationship or claim is important or critical to the stakeholder.

The interaction of the three attributes result in three classes of stakeholders: latent, expectant and definitive (Mitchell et al., 1997). The latent group comprises dormant stakeholders, possessing the attribute power; discretionary stakeholders possessing legitimacy; and demanding stakeholders, possessing the attribute urgency. The expectant group comprises dominant stakeholders, possessing power and legitimacy; dependent, possessing legitimacy and urgency; and dangerous, possessing power and urgency. The definitive group comprises stakeholders possessing all three attributes. Any expectant stakeholder can become a definitive stakeholder by acquiring the missing attribute. Parent \& Deephouse (2007) suggest that most stakeholders were definitive, dominant or dormant. This would indicate that power and legitimacy are the most likely attributes to present. The Mitchell et al. (1997) model has been applied many times and proves the usefulness of the model in studying stakeholder relationships in this study. Table 1 presents a summary of some studies applying the model. 
Table 1. Application of the Mitchell et al (1997) model

\begin{tabular}{cl}
\hline Authors Application & Year \\
\hline Elijido-Ten et al & 2010 Empirical \\
Baskerville-Morley & 2004 Empirical \\
Neville and Mengue & 2006 Theoretical \\
O'Higgins and Morgan & 2006 Empirical \\
Cummings and Guthrie & 2007 Empirical \\
Parent and Deephouse & 2007 Empirical \\
Currie, Seaton and Wesley & 2009 Empirical \\
Magness & 2008 Empirical \\
Boesso and Kumar & 2007 Empirical \\
\hline
\end{tabular}

Once management is aware of its stakeholders, the company strategy is then aligned with these stakeholders' needs (Wolfe \& Putler, 2002; Suddaby et al., 2013). The relationship between strategy and stakeholders was discussed in some of Freeman's (1984: 74) research: 'To be an effective strategist you must deal with those groups that can affect you, while to be responsive (and effective in the long run) you must deal with those groups that you can affect.' Following on from this, analysing the strategic actions an organisation takes in response to stakeholders may help us better understand the organisation's relationship with its stakeholders. Oliver's (1991) institutional response model suggests ways of responding to stakeholders. Therefore this study involves integrating stakeholder and institutional theory and more specifically, the Mitchell et al. (1997) and Oliver (1991) models.

\section{Institutional Theory}

Institutional theory provides another useful way of explaining factors that influence the adoption of systems in organisations (Ansari \& Euske, 1987; Abernethy \& Stoelwinder, 1995; Abernethy \& Chua, 1996; Abernethy \& Brownwell, 1997; Brignell \& Modell, 2000; Lapsley \& Pallott, 2000; Modell 2001; Touron 2005). As Oakes et al. (1998:259) note: 'organisations are constructed through institutionalized practices and historical experiences that construct normative models of organizational legitimacy.'Traditionally, institutional theorists focused on a two party framework of stakeholders for public sector organisations, namely funding bodies and professional service providers. This traditional two party framework was broadened by Brignall \& Modell (2000) to include a third party, the purchasers of public services. There are four factors in institutional theory which are considered important for the survival of an organisation: legitimacy, dependency, consistency and control.

An organisation's ability to survive depends on conforming to social norms and attaining legitimacy from stakeholders (Yang \& Modell, 2013; Monfardini et al., 2013; Irvine, 2011; Makela \& Nasi, 2010; Nasi (cited in Mitchell et al., 1997); Zucker, 1988; Zucker, 1987; DiMaggio \& Powell 1983). Stakeholders, such as professional associations, outside interest groups, the state and public opinion create pressures that can cause organisations to change their control systems and structure, without any evidence that this will increase efficiency and effectiveness (Dacin et al., 2002; DiMaggio \& Powell, 1983; Meyer \& Rowan, 1977; Scott, 1987; Powell \& DiMaggio, 1991; Scott \& Christensen, 1995). In stakeholder theory the concept of pressure exerted from external constituents has been much discussed but the literature has not addressed the typology of constituents or stakeholders exerting the pressure, and whether the stakeholder typology is an influencing factor in attaining legitimacy. I contend that organisations must attain legitimacy from definitive, dominant, dependent and discretionary stakeholders in order to survive.

From an institutional perspective, dependency on stakeholders is thought to influence the actions managers take in dealing with them. (Myer et al., 1987 \& Gupta et al., 1994) have investigated the types of pressure constituents (stakeholders) exert on organisations. The research was premised on the assumption that to secure legitimacy, practices employed by an organisation were only ever symbolic and always decoupled from internal operating systems. This assumption has been questioned (Carruthers, 1995, Chua, 1995; Mouritsen, 1994). Oliver (1991) suggests that in response to institutional pressures an organisation's management enacts a specific strategic response. Dependency on stakeholders is thought to influence the action managers take in dealing with stakeholders. Dependency on external constituents will influence the way management and the organisation react to these constituents (DiMaggio \& Powell, 1983; Oliver, 1991; Pfeffer \& Salancik, 1978). Dependency can have different forms: an organisation can be dependent on a stakeholder for financial or other scarce resources. It can also be that an organisation is dependent on a stakeholder for survival. Co-dependency is another form: a stakeholder is dependent on the organisation and the organisation is dependent on the stakeholder. When an 
organisation is heavily dependent on another DiMaggio \& Powell (1983:154) hypothesise that 'The greater the dependence of an organisation on another organisation, the more similar it will become to that organisation in structure, climate, and behavioural focus.'

From a stakeholder perspective, dependency on stakeholders occurs when those stakeholders possess the attributes of legitimacy and urgency. Dependency of public sector units is considered for this research. Government owned organisations could be dependent on other organisations, for example private sector companies, to meet organisational objectives. This could be a potential problem if the two organisations have very different philosophies. Therefore, the consistency between these organisations is another factor which could impact on management's strategic response in dealing with the external stakeholder or organisation (Oliver 1991).

Consistency and inconsistency has been widely discussed (Clemens \& Douglas, 2005; Covaleski \& Dirsmith, 1988; DiMaggio \& Powell, 1983; Oliver 1991; Whetten 1978). 'Inconsistency reflects organisational interests at cross purposes with institutional objectives and provokes organisational doubts about the validity or legitimacy of institutional expectations' (Oliver, 1991: 165). This could be a problem for government owned entities with social and economic objectives and was raised by Martin (1996) when questioning if corporatisation and community service obligations were indeed compatible. Inconsistency between organisational goals is potentially a complex and difficult situation for managers. This is indeed one of the motives for this research. The manner in which these demands are placed on the organisation, in other words through what form of control the demands are exercised is also expected to influence the way in which managers will react to these inconsistent pressures.

'Institutional control describes the means by which pressures are imposed on organisations' (Oliver, 1991: 168). Control has been widely researched (Clemens \& Douglas, 2004; DiMaggio \& Powell, 1983; Dacin et al., 2002; Oliver, 1991; Pfeffer\&Salancik, 1978; Scott 1987 to name but a few). The way in which control is exercised is considered by Oliver (1991) to be a predictor of strategic response. Pressures or isomorphic forces from an organisation's institutional environment cause the adoption of certain practices (Abernethy \& Chua, 1996; DiMaggio \& Powell, 1983; Meyer \& Rowan, 1977; Scott, 1987). Three types of isomorphic forces have been identified: coercive, mimetic and normative (DiMaggio \& Powell, 1983).

Coercive isomorphism can be attributed to a common regulatory environment at all government levels, requiring adoption of controls to meet legal obligations (DiMaggio \& Powell, 1983). Coercive force is exceptionally strong where deviations from institutional norms have legal, moral or economic implications, such as incurring fines or loss of reputation (Kondra \& Hinings, 1998). Mimetic force is a powerful factor encouraging imitation and causes managers to adopt practices where others perceived as successful have adopted them (DiMaggio \& Powell, 1983; Oliver 1991). The adoption of some forms of Management Control Systems (MCS) in public sector organisations may be the result of mimetic force (Brignall\& Modell, 2000; Chua 1995; Covaleskiet al., 1996; Lapsley\&Pallot, 2000). This is demonstrated in the public sector environment by organisations adopting NPM techniques previously thought appropriate in private sector environments (Brignall \& Modell, 2000; Hood 1991; Lapsley\&Pallot, 2000). Normative force arises when norms are shared among members of a recognised profession to establish acceptable practice (DiMaggio \&Powell, 1983; Scott 1987). Therefore it tends to be associated with the adoption of systems due to professionalisation. Associations and professional bodies (such as accounting bodies) can influence the adoption of MCS (Abernethy \&Stoelwinder, 1995; Abernethy \& Chua, 1996; Brignall \& Modell, 2000; Chua 1995; Touron, 2005). Peer groups (for example MBA graduates) and professional associations typically support the adoption of practices that improve effectiveness (Modell 2001).

The way in which control is exercised on public sector organisations is often through Government mandate or coercion through legislation, regulation, reforms and calls for transparency and accountability. The consequences of non-compliance with government mandates would likely result in severe penalties. These pressures may also occur through voluntary diffusion (Oliver 1991); meaning that if they have already been taken up by other organisations in the field they will likely result in conformity, but that will depend on the number of organisations who have adopted the requirement or practice. However, in a NPM environment, normative (the move of private sector professionals into the public sector) and mimetic (mimicking private sector practices) control may also arise. Following on from this literature on institutional theory, the Oliver (1991) model of strategic responses is discussed in the next section.

\subsection{Oliver's (1991) Model}

Oliver's (1991) model predicts conditions under which organisations will resist pressures to conform and those under which organisations may adhere to institutional pressures. Managers respond to demands across a 
continuum, from passive conformity to active resistance. Oliver (1991) suggests that responses depend on several factors, some of which were discussed above: legitimacy, dependency, consistency and control. The strategic responses to institutional pressure are acquiescence, compromise, avoid, defy and manipulate. A strategic response of acquiescence represents compliance with institutional pressures and is found at the passive conformity end of the strategic response continuum. Manipulation is found at the active resistance end of the continuum, and according to Oliver (1991:157) can be defined as 'the purposeful and opportunistic attempt to co-opt, influence, or control institutional pressures and evaluations.' However, Clemens \& Douglas (2004:1211) find '...from the firm's perspective, this strategy may represent an attempt to participate in the institutional process in a productive manner'. In between these ends are compromise and defiance. Oliver (1991) suggests that there are three tactics employed in the spirit of conforming and accommodating institutional rules, norms, or values. These three compromise tactics are balancing, pacifying and bargaining. She suggests 'in contrast to acquiescence, institutional compliance is only partial and organisations are more active in promoting their own interests (Oliver 1991:154). A defiant strategy...represents unequivocal rejection of institutional norms and expectations, and it is more likely to occur ... when organisations believe they have little to lose by displaying their antagonism toward the constituents that judge or oppose them (Oliver 1991, pp. 157).

Oliver's (1991) model thus offers a typology of strategic responses to institutional pressures that vary in active organisational resistance from passive conformity to proactive manipulation. Oliver (1991) also hypothesised five predictive factors influence management decision making and result in this continuum of strategic responses from passive conformity (acquiescence) to active resistance (defy or manipulate).

\subsection{Predictive Factors of Strategic Response}

Oliver's (1991) model suggests five dimensions of strategic response: cause (legitimacy and efficiency); constituents (multiplicity and dependence); content (consistency and discretionary constraints); control (legal coercion and voluntary diffusion of norms) and context (environmental uncertainty and interconnectedness). A summary of the predictive factors and strategic responses is presented in Table 2 and discussed, below.

Table 2. Institutional antecedents and predicted strategic responses

\begin{tabular}{|c|c|c|c|c|c|}
\hline \multirow{2}{*}{ Predictive factor } & \multicolumn{5}{|c|}{ Strategic responses } \\
\hline & Acquiesce & Compromise & Avoid & Defy & Manipulate \\
\hline \multicolumn{6}{|l|}{ Cause } \\
\hline Legitimacy & High & Low & Low & Low & Low \\
\hline Efficiency & High & Low & Low & Low & Low \\
\hline \multicolumn{6}{|l|}{ Constituents } \\
\hline Multiplicity & Low & High & High & High & High \\
\hline Dependence & High & High & Moderate & Low & Low \\
\hline \multicolumn{6}{|l|}{ Content } \\
\hline Consistency & High & Moderate & Moderate & Low & Low \\
\hline Constraint & Low & Moderate & High & High & High \\
\hline \multicolumn{6}{|l|}{ Control } \\
\hline Coercion & High & Moderate & Moderate & Low & Low \\
\hline Diffusion & High & High & Moderate & Low & Low \\
\hline \multicolumn{6}{|l|}{ Context } \\
\hline Uncertainty & High & High & High & Low & Low \\
\hline Interconnectedness & High & High & Moderate & Low & Low \\
\hline
\end{tabular}

Source: Oliver (1991:160).

The cause of institutional pressures refers to why the organisation is being pressured to conform. Oliver (1991) predicts that when an organisation expects conformity to increase social (legitimacy) or economic (efficiency) fitness, acquiescence will be the most likely strategic response to pressure from external constituents. When an organisation expects that conformity will result in no or little increase or improvement in social or economic fitness, any of the other strategic responses may be employed by the organisation.

From the discussion on Oliver's (1991) and Mitchell et al. (1997) models above, some synergies between the models emerge. Both Oliver (1991) and Mitchell et al. (1997) use the notion of legitimacy in their models, albeit in slightly different contexts. Oliver (1991) refers to cause in the form of legitimacy or social fitness and in the 
form of efficiency or economic fitness as predictive factors in an organisation's strategic response to pressure from external stakeholders. Mitchell et al. (1997) claim that an organisation will take more notice of a stakeholder where it is perceived that the stakeholder relationship is a legitimate one that is appropriate, proper and desirable in the social context. Both these models imply that legitimacy is concerned with fitness in the social context.In a public sector context, post NPM, the models together provide a theoretical underpinning for acquiescence when the stakeholder is the government which has coercive powers to ensure conformance. Mimetic pressures (Oliver) arise when the organisation expects conformity with private sector practices to increase economic efficiency, often a goal of the government stakeholder (Mitchell et al., 1997).

Where multiple constituents exist in the institutional environment of an organisation Oliver (1991) predicts the acquiescence response to be low, and the compromise, avoid, defy or manipulate responses to be high. Oliver (1991) also argues that the level of dependency of the organisation on these constituents will impact on the strategic response of the organisation. Organisations will tend to manipulate or defy where dependency on the external constituent is low. When dependency on the external constituent is high, the organisational response will tend to be acquiescence or compromise. Oliver's focus is on the number (multiplicity) of stakeholders in the institutional environment and the dependency of the organisation on these stakeholders. Mitchell et al. (1997) framework, focus on stakeholders is that of the attributes of the identified stakeholders. This enhances Oliver's model by providing a mechanism for prioritising Oliver's multiple stakeholders, and in turn Mitchell et al's model is enhanced by Oliver's perspectives. Using both models provides a theory to assist public sector organisations in an NPM environment with multiple stakeholders/constituents with conflicting demands: economic efficiency or social benefits.

Content refers to the norms or requirements the organisation is being pressured to conform to (Oliver 1991). Organisations will be more willing to acquiesce to external pressures when these pressures or expectations are compatible with internal goals (Oliver, 1991:165). Whetten (cited in Oliver 1991) predicts non-profit organisations may be more resistant to pressures for economic rationality because compliance with these pressures may be perceived as inconsistent with the goal of high quality social service delivery. However, in light of NPM, this prediction may need to be modified as corporatised government entities are expected to provide social services as well as perform in an economically rational way. Compromise and avoidance strategies are predicted to be most common when there is only moderate consistency between organisational goals and institutional pressures; defiance and manipulation strategies are predicted to occur most frequently when consistency is low (Oliver, 1991:165). Such inconsistencies are likely to occur when there are multiple stakeholders such as government resource providers and the community as resource users. Pfeffer and Salancik (cited in Oliver, 1991) suggest 'compliance is a loss of discretion, a constraint, and an admission of limited autonomy.' Organisations are expected to acquiesce more readily to pressures that do not constrain substantive organisational decisions, such as resource allocation, product or service selection, resource acquisition, or organisational administration (Oliver, 1991: 166).

Institutional control describes the means by which pressures are imposed on organisations. Two distinct processes by which pressures are exerted include legal coercion and voluntary diffusion (Oliver 1991). When legal coercion is high, a strategic response of acquiescence best serves the interests of the organisations (Oliver 1991:168). When sanctions for non-compliance are minimal, consequences of nonconforming behaviour may not constitute a sufficient deterrent to organisational resistance.Oliver (1991) also notes that 'the extent to which an institutional expectation or practice has already diffused or spread voluntarily through an organisational field will tend to predict the likelihood of conformity to institutional expectations.'

While Mitchell et al. (1997) refer's to power as a determinant of organisational management response or taking note of the organisation, Oliver (1991) refers to control as a determinant of organisational strategic response. These two views are entirely consistent; Mitchell et al. (1997) predict that an organisation's management will take note of a stakeholder they perceive to be powerful, including the use of legal power. In other words the organisation's management will tend to yield to pressure from a powerful stakeholder. Oliver's (1991) model, refers to how control is exercised, for example through legal coercion or voluntary diffusion. Again, in an NPM context, legal power or coercion by a government stakeholder on a public sector entity will have a strong impact on the strategic response.

Oliver (1991) considers the environmental context within which institutional pressures are exerted and predicts that environmental uncertainty and environmental interconnectedness are significant dimensions that affect organisations' conformity or resistance to institutional demands and expectations. Environmental uncertainty is defined by Pfeffer \& Salancik (cited in Oliver, 1991: 67) as 'the degree to which future states of the world cannot be anticipated and accurately predicted.' Interconnectedness refers to the density of interorganisational 
relations among occupants of an organisational field (Aldrich \&Whetten cited in Oliver 1991; DiMaggio \& Powell, 1983; Pfeffer\&Salancik, 1978). Oliver (1991) predicts that acquiescence and compromise strategies will be most likely to occur when environmental uncertainty is high. DiMaggio \& Powell (1983) hypothesise that environmental uncertainty causes organisations to mimic one another. Oliver (1991) predicts that organisations are more likely to accede to the values or requirements of the institutional environment when this environment is highly interconnected. 'Interconnectedness refers to the density of interorganisational relations among occupants of an organisational field.' (Aldrich \& Whetten, 1984; DiMaggio \& Powell, 1983; Pfeffer \& Salancik, 1978).

To capture the dynamics of the stakeholder-manager interactions Mitchell et al. (1997) propose that adding the attribute of urgency helps move the model from static to dynamic. The attribute urgency is based on time sensitivity and criticality (Mitchell et al., 1997). Oliver's (1991) model also draws on time sensitivity in the context predictor. She refers to environmental uncertainty with a focus on the anticipated future state of the world and the impact of this on the strategic response of the organisations management.

\section{Types of Strategic Responses}

Oliver (1991) suggests five strategic responses and relevant tactics: acquiesce, compromise, avoid, defy and manipulate. This framework is enhanced by incorporating the Mitchell et al. (1997) model.

A strategic response of acquiescence represents compliance with institutional pressures at the passive conformity end of the strategic response continuum (Oliver, 1991). This response can take alternative forms, habit 'following invisible taken for granted norms', imitate 'mimicking institutional models' and comply 'obeying rules and accepting norms' (Oliver, 1991:152). In an NPM context, acquiescence is a likely strategic response to a definitive stakeholder such as a government resource provider, and also to stakeholders such as employees who belong to professional bodies.

Where an organisation considers unqualified conformity unpalatable or unworkable and where conflicting demands are required, compromise may be the strategic response enacted. The tactics employed include balance 'balancing the expectations of multiple constituents' pacify 'placating and accommodating institutional elements' and bargain 'negotiating with institutional stakeholders' (Oliver, 1991). Balance is particularly critical when organisations must attempt to satisfy conflicting demands of multiple stakeholders. This is a common situation for public sector organisations with several definitive stakeholders.

Avoidance as a response to demands can also be enacted and many involve an organisational attempt to conceal their non-conformity or buffer themselves from pressures. The tactics include, conceal 'disguising nonconformity', buffer 'loosening institutional attachments' and escape 'changing goals, activities, or domains' (Oliver, 1991, pp. 153). Avoidance can be a response to latent and dependent stakeholders (Mitchell et al., 1997). Avoidance is less likely to be a response to dominant, dangerous and definitive stakeholders, all of which have power in their relationships with the organisation. For public sector organisations, avoidance can be a response to demands from the community, but less likely to be a response to demands from government.

Defiance represents unequivocal rejection of institutional pressures and this is likely to occur when management consider the cost of defiance to be low. The tactics employed include, dismiss 'ignoring explicit norms and values', challenge 'contesting rules and requirements' and attack 'assaulting the sources of institutional pressure' (Oliver, 1991, pp. 156). Again, the salience of stakeholders (Mitchell et al., 1997) is likely to influence whether management resorts to defiance.

Manipulation is found at the active resistance end of the strategic response continuum, and according to Oliver (1991, pp. 157) can be defined as 'the purposeful and opportunistic attempt to co-opt, influence, or control institutional pressures and evaluations. Co-opting involves 'importing influential constituents', influence 'shaping values and norms' and control dominating institutional constituents and processes' (Oliver 1991, pp. 157). It is likely that the less important stakeholders which can be identified through the Mitchell et al., (1997) model can be manipulated.

\section{New Propositions}

Stakeholder theory predicts organisations take most notice of stakeholders who possess the three attributes of power, legitimacy and urgency (Mitchell et al., 1997). Institutional theory predict organisations acquiesce, compromise, avoid, defy or manipulate stakeholders in response to institutional demands on the basis of several determinants that affect their willingness and ability to comply (Oliver, 1991). As I have shown above, combining these two theoretical positions links stakeholder type with an explicit strategic response for a more powerful theoretical framework. 
A strategic response of acquiescence represents compliance at the passive conformity end of the strategic response continuum (Oliver, 1991). An organisation is more likely to take notice i.e. acquiesce with the demands of a definitive or more salient stakeholder (Mitchell et al., 1997). It is less likely to take notice of or acquiesce with the demands of less salient and single attribute dormant, discretionary or demanding stakeholders, with a response towards the active resistance end of the response continuum. Dominant, dependent and dangerous stakeholders, each possessing two attributes, have some salience and the organisation will tend to show both some resistance and some acquiescence to institutional pressures. Dormant stakeholders possess only the power attribute, but neither legitimacy nor urgency.However, not all dormant stakeholders are the same. Some, such as government through legislation or funding, may have coercive power; others such as professional organisations may have symbolic or normative power.

I postulate the following new propositions:

Proposition P1a: The higher the number of attributes the stakeholder possesses the greater the likelihood of a strategic response towards the passive conformity end of the strategic response continuum.

Proposition P1b: The lower the number of attributes the stakeholder possesses the greater the likelihood of a strategic response towards the active resistance end of the strategic response continuum.

Proposition P2a: When a stakeholder possesses the attribute power, if the power is perceived to be coercive, the greater the likelihood of a strategic response more towards the passive conformity end of the strategic response continuum.

Proposition P2b: When a stakeholder possesses the attribute power, if the power is perceived to be symbolic, the greater the likelihood of a strategic response more towards the active resistance end of the strategic response continuum.

Proposition P3a: When management has high dependency on a stakeholder and legitimacy is perceived to be gained, the greater the likelihood of a strategic response more towards the passive conformity end of the strategic response continuum.

Proposition P3b: When management has low dependency on a stakeholder and legitimacy is perceived to be gained, consistency is high and control is enforced through legal coercion the likelihood remains of a strategic response more towards the passive conformity end of the strategic response continuum.

These propositions suggest another way to predict and examine how institutional pressure influences how organisations respond to various stakeholders.

\section{Discussion and Future Research}

This paper has reviewed stakeholder and institutional theories, and explored how a combination of them may enhance our understanding of how organisations respond to multiple stakeholders' and their often conflicting interests. This is of particular importance to public sector organisations in a NPM context especially those which have been privatised or corporatised. Multiple stakeholders may include governments which want efficient and economic services; the service users who want high quality and often unlimited services; the general community who frequently want good services combined with lower taxes; private sector competitors who often want restrictions on public organisations' operations; employees who want to exercise their professional (and personal) obligations; and professional bodies and unions who want to impose a particular world view. Stakeholder theory assists us in identifying the stakeholders and a way to prioritise them when trying to satisfy diverse objectives: institutional theory suggests a way to identify the coercive, mimetic and normative pressures brought to bear on management by different stakeholders and how to respond strategically to them, given the salience of each stakeholder type. Using the multiple perspectives developed in the propositions in this paper provides a richer theoretical framework for understanding how managers respond to often very challenging environments which include a diversity of stakeholders, both external and internal.

In practical terms, this paper provides a conceptual framework for managers to understand and develop practices and policies for better operating outcomes. This research therefore presents an avenue for future research with these new propositions posing the impetus to research practices experienced by management in public sector organisations, their responses, and their outcomes. The public sector is an ideal testing environment as corporatised public bodies in particular have a very wide range of salient stakeholders. The findings from this future research will help develop a greater understanding of the influence of stakeholder types on managers' strategic responses to institutional pressures. 


\section{References}

Abernethy, M. A., \& Chua, W. F. (1996). A Field Study of Control System "Redesign": The Impact of Institutional Processes on Strategic Choice. Contemporary Accounting Research, 13(2), 569-606.

Abernethy, M. A., \& Stoelwinder, J. U. (1995). The role of professional control in the management of complex organizations. Accounting, Organizations and Society, 20(1), 1-17.

Abernethy, M. A., \& Brownell, P. (1997). Management control systems in research and development organizations: The role of accounting, behavior and personnel controls. Accounting, Organizations and Society, 22(3-4), 233-248.

Agle, B. R., Mitchell, R. K., \& Sonnenfeld, J. A. (1999). Who matters to CEOs? An investigation of stakeholder attributes and salience, corporateperformance, and CEO values. Academy of Management Journal, 42(5), $507-525$.

Ansari, S., \& Euske, K. J. (1987). Rational, rationalizing, and reifying uses of accounting data in organizations. Accounting, Organizations and Society, 12(6), 549-570.

Boesso, G., \& Kumar, K. (2007). Drivers of corporate voluntary disclosure: a framework and empirical evidence from Italy and the United States. Accounting, Auditing \& Accountability Journal, 20(2), 269-296.

Brignall, S., \& Modell, S. (2000). An institutional perspective on performance measurement and management in the new public sector. Management Accounting Research, 11(3), 281-306.

Buchholz, R., \& Rosenthal, S. (2004). Stakeholder Theory and Public Policy: How Governments Matter. Journal of Business Ethics, 51(2), 143-153.

Bundy, J., Shropshire, C., \& Bucholtz, A. K. (2013). Strategic Cognition and Issue Salience: Toward an explanation of firm responsiveness to stakeholder concerns. Academy of Management Review, 38(3), 352-376.

Carruthers, B. G. (1995). Accounting, ambiguity, and the new institutionalism. Accounting, Organizations and Society, 20(4), 313-328.

Chua, W. F. (1995). Experts, networks and inscriptions in the fabrication of accounting images: A story of the representation of three public hospitals. Accounting, Organizations and Society, 20(2-3), 111-145.

Clarkson, M. E. (1995). A stakeholder framework for analyzing and evaluating corporate social performance. Academy of Management Review, 20(1), 92-117.

Clemens, B. W., \& Douglas, T. J. (2005). Understanding strategic responses to institutional pressures. Journal of Business Research, 58(9), 1205-1213.

Collier, P. (2008). Stakeholder accountability: A field study of the implementation of a governance improvement plan. Accounting, Auditing \& Accountability Journal, 21(7), 933-954.

Covaleski, M. A., \& Dirsmith, M. W. (1988). The use of budgetary symbols in the political arena: An historically informed field study. Accounting, Organizations and Society, 13(1), 1-24.

Currie, R., Seaton, S., \& Wesley, F. (2009). Determining stakeholders for feasibility analysis. Annals of Tourism Research, 36(1), 41-63.

Dacin, M. T., Goodstein, J., \& Scott, W. R. (2002). Institutional theory and Institutional change: Introduction to the special research forum. Academy of Management Journal, 45(1), 45-56.

Darnall, N., Seol, I., \& Sarkis, J. (2009). Perceived stakeholder influences and organizations' use of environmental audits. Accounting, Organizations and Society, 3(2), 170-187.

Deephouse, D. L. (1996). Does Isomorphism Legitimate? Academy of Management Journal, 39(4), 1024-1039.

DiMaggio, P. J., \& Powell, W. W. (1983). The Iron cage revisited: Institutional isomorphism and collective rationality in organizational fields. American Sociological Review, 48(2), 147-160.

Donaldson, T., \& Preston, L. E. (1995). The stakeholder theory of the corporation: concepts, evidence, and implications. Academy of Management Review, 20(1), 65-91.

Edgley, C. R., Jones, M. J., \& Solomon, J. F. (2010). Stakeholder inclusivity in social and environmental report assurance. Accounting, Auditing \& Accountability Journal, 23(4), 532-557.

Eesley, C., \& Lenox, M. J. (2006). Firm responses to secondary stakeholder action. Strategic Management Journal, 27(8), 765-781. 
Elijido-Ten, E., Kloot, L., \& Clarkson, P. (2010). Extending the application of stakeholder influence strategies to environmental disclosures: An exploratory study from a developing country. Accounting, Auditing \& Accountability Journal, 23(8), 1032-1059.

Freeman, R. E. (1984). Strategic management: A stakeholder approach. Pitman, Marshfield.

Friedman, A. L., \& Miles, S. (2002). Developing stakeholder theory. Journal of Management Studies, 39(1), $1-21$.

Frooman, J. (1999). Stakeholder Influence Strategies. Academy of Management Review, 24(2), 191-205.

Gupta, P. P., Dirsmith, M. W., \& Fogarty, T. J. (1994). Coordination and Control in a Government Agency: Contingency and Institutional Theory Perspectives on GAO Audits. Administrative Science Quarterly, $39(2), 264-284$.

Hannele, M. S. (2010). Social responsibilities of MNCs in downsizing operations: A Finnish forest sector case analysed from the stakeholder, social contract and legitimacy theory point of view. Accounting, Auditing \& Accountability Journal, 23(2), 149-174.

Harrison, J. S., \& Wicks, A. C. (2013). Stakeholder Theory, Value, and Firm Performance. Business Ethics Quarterly, 23(1), 97-124.

Hinings, C. R., \& Greenwood, R. (2002). Disconnects and Consequences in Organization Theory? Administrative Science Quarterly, 47(3), 411-421.

Hood, C. (1991). A public management for all seasons? Public Administration, 69(1), 3-19.

Hosseini, J. C., \& Brenner, S. N. (1992). The stakeholder theory of the firm: A methodology to generate value matrix weights. Business Ethics Quarterly, 2(2), 99-119.

Irvine, H. (2011). From go to woe: How a not-for-profit managed the change to accrual accounting. Accounting, Auditing \& Accountability Journal, 24(7), 824-847.

Jensen, M. C. (2002). Value maximization, stakeholder theory, and the corporate objective function. Business Ethics Quarterly, 12(2), 235-256.

Jones, T. M. (1995). Instrumental stakeholder theory: A synthesis of ethics and economics. Academy of Management Review, 20(2), 404-437.

Key, S. (1999). Toward a new theory of the firm: a critique of stakeholder theory. Management Decision, 37(3/4), 317.

Kloot, L., \& Martin, J. (2000). Strategic performance management: A balanced approach to performance management issues in local government. Management Accounting Research, 11(2), 231-251.

Knox, S., \& Gruar, C. (2007). The Application of Stakeholder Theory to Relationship Marketing Strategy Development in a Non-profit Organization. Journal of Business Ethics, 75(2), 115-135.

Kondra, A. Z., \& Hinings, C. R. (1998). Organizational diversity and change in institutional theory. Organization Studies (Walter de Gruyter GmbH \& Co. KG.), 19(5), 743.

Laplume, A., Sonpar, K., \& Litz, R. A. (2008). Stakeholder Theory: Reviewing a Theory That Moves Us. Journal of Management, 34(6), 1152-1189.

Lapsley, I., \& Pallot, J. (2000). Accounting, management and organizational change: A comparative study of local government. Management Accounting Research, 11(2), 213-229.

Lee, J. (2006). Performance reporting by Australian Government Trading Enterprises: An empirical study 1998-2002. Australian Accounting Review, 16(2), 34.

Mäkelä, H., \& Näsi, S. (2010). Social responsibilities of MNCs in downsizing operations: A Finnish forest sector case analysed from the stakeholder, social contract and legitimacy theory point of view. Accounting, Accountability and Auditing Journal, 23(2), 149-174.

Martin, J. (1996). Corporatisation and community service obligations: Are they incompatible? Australian Journal of Public Administration, 55(3), 111.

Meyer, J. W., \& Rowan, B. (1977). Institutionalized Organizations: Formal Structure as Myth and Ceremony. American Journal of Sociology, 83(2), 340-363.

Meyer, J., Scott, W. R., \& Strang, D. (1987). Centralization, Fragmentation, and School District Complexity. Administrative Science Quarterly, 32(2), 186-201. 
Mitchell, R. K., Agle, B. R., \& Wood, D. J. (1997). In Academy of Management Review. Academy of Management, 22(4), 853-886.

Modell, S. (2001). Performance measurement and institutional processes: a study of managerial responses to public sector reform. Management Accounting Research, 12, 437-464.

Monfardini et al. (2013). Seeking legitimacy: Social reporting in the healthcare sector. Accounting Forum, 37(1), $54-66$.

Mouritsen, J. (1994). Rationality, institutions and decision making: Reflections on March and Olsen's rediscovering institutions. Accounting, Organizations and Society, 19(2), 193-211.

Oakes, L. S., Townley, B., \& Cooper, D. J. (1998). Business Planning as Pedagogy: Language and Control in a Changing Institutional Field. Administrative Science Quarterly, 43(2), 257-92.

Oates, G., \& Kloot, L. (2013). Corporatised public land development bodies in Australia: Who are the stakeholders and why are they important? International Journal of Public Administration, 36(14).

O'Higgins, E. R. E., \& Morgan, J. W. (2006). Stakeholder salience and engagement in political organisations: Who and what really counts? Society and Business Review, 1(1), 62-76.

Oliver, C. (1991). Strategic responses to institutional processes. Academy of Management Review, 16, 145-179.

Parent, M. M., \& Deephouse, D. L. (2007). A case study of stakeholder identification and prioritization by managers. Journal of Business Ethics, 75(1), 1-24.

Pfeffer, J., \& Salancki, G. (1978). The External Control of Organisations: A Resource Dependence Perspective. New York: Harper and Row,

Powell, W., \& DiMaggio, P. (1991). The New Institutionalism in Organisational Analysis. Chicago, University of Chicago Press.

Purdy, J. M., \& Gray, B. (2009). Conflicting logics, mechanisms of diffusion, and multilevel dynamics in emerging institutional fields. Academy of Management Journal, 52(2), 355-380.

René, O. (2010). Corporate social disclosures in the context of national cultures and stakeholder theory. Accounting, Auditing \& Accountability Journal, 23(7), 868-889.

Scott, W. R. (1987). The Adolescence of Institutional Theory. Administrative Science Quarterly, 32(4), 493-511.

Scott, W. R., \& Christensen, S. (1995). The Institutional Construction of Organisations: International and Longitudinal Studies. SAGE.

Smith, W. K., Gonin, M., \& Besharov, M. L. (2013). Managing Social-Business Tensions: A Review and Research Agenda for Social Enterprise. Business Ethics Quarterly, 23(3), 407-442.

Stern, R. N., \& Barley, S. R. (1996). Organizations and Social Systems: Organization Theory's Neglected Mandate. Administrative Science Quarterly, 41(1), 146-162.

Suddaby, R., Seidl, D., \& Lê, J. K. (2013). Strategy-as-practice meets neo-institutional theory' Strategic Organization, 11(3), 329-344.

Touron, P. (2005). The adoption of US GAAP by French firms before the creation of the International Accounting Standard Committee: an institutional explanation. Critical Perspectives on Accounting, 16(6), 851-873.

Verbeke, A., \& Tung, V. (2013). The Future of Stakeholder Management theory: A temporal Perspective.

Whetten, D. A. (1978). Coping with Incompatible Expectations: An Integrated View of Role Conflict. Administrative Science Quarterly, 23(2), 254-271.

Winn, M. I. (2001). Building stakeholder theory with a decision modelling methodology. Business \& Society, 40(2), 133-166.

Wolfe, R. A., \& Putler, D. S. (2002). How Tight Are the Ties that Bind Stakeholder Groups? Organization Science, 13(1), 64-80.

Wood, D. J. (1991). Corporate social performance revisited. Academy of Management Review, 16(4), 691-718. 
Yang, C. L., \& Modell, S. (2013). Power and performance: Institutional embeddedness and performance management in a Chinese local government organization. Accounting, Auditing \& Accountability Journal, 26(1), 101-132.

Zucker, L. (1987). Institutional Theories of Organisations. Annual Review of Sociology, 13, 443-464.

Zucker, L. (1988). Institutional Patterns and Organisations: Culture and Environment. Cambridge: Ballinger Publishing Company.

\section{Copyrights}

Copyright for this article is retained by the author(s), with first publication rights granted to the journal.

This is an open-access article distributed under the terms and conditions of the Creative Commons Attribution license (http://creativecommons.org/licenses/by/3.0/). 